\title{
Coral $\mathrm{Cd} / \mathrm{Ca}$ and $\mathrm{Mn} / \mathrm{Ca}$ records of ENSO variability in the Gulf of California
}

\author{
J. D. Carriquiry and J. A. Villaescusa \\ Instituto de Investigaciones Oceanológicas, Universidad Autónoma de Baja California, Apdo. Postal No. 453, Ensenada, \\ Baja California, México
}

Received: 25 December 2009 - Published in Clim. Past Discuss.: 5 February 2010

Revised: 7 June 2010 - Accepted: 14 June 2010 - Published: 28 June 2010

Abstract. We analyzed the trace element ratios $\mathrm{Cd} / \mathrm{Ca}$ and $\mathrm{Mn} / \mathrm{Ca}$ in three coral colonies (Porites panamensis (19671989), Pavona clivosa (1967-1989) and Pavona gigantea (1979-1989)) from Cabo Pulmo reef, Southern Gulf of California, Mexico, to assess the oceanographic changes caused by El Niño - Southern Oscillation (ENSO) events in the Eastern Tropical North Pacific (ETNP). Interannual variations in the coral $\mathrm{Cd} / \mathrm{Ca}$ and $\mathrm{Mn} / \mathrm{Ca}$ ratios showed clear evidence that incorporation of $\mathrm{Cd}$ and $\mathrm{Mn}$ in the coral skeleton was influenced by ENSO conditions, but the response for each metal was controlled by different processes. The $\mathrm{Mn} / \mathrm{Ca}$ ratios were significantly higher during ENSO years $(p<0.05)$ relative to non-ENSO years for the three species of coral. In contrast, the $\mathrm{Cd} / \mathrm{Ca}$ was systematically lower during ENSO years, but the difference was significant $(p<0.05)$ only in Pavona gigantea. A decrease in the incorporation of $\mathrm{Cd}$ and a marked increase in $\mathrm{Mn}$ indicated strongly reduced vertical mixing in the Gulf of California during the mature phase of El Niño. The oceanic warming during El Niño events produces a relaxation of upwelling and a stabilization of the thermocline, which may act as a physical barrier limiting the transport of $\mathrm{Cd}$ from deeper waters into the surface layer. In turn, this oceanic condition can increase the residence time of particulate-Mn in surface waters, allowing an increase in the photo-reduction of particulate-Mn and the release of available $\mathrm{Mn}$ into the dissolved phase. These results support the use of $\mathrm{Mn} / \mathrm{Ca}$ and $\mathrm{Cd} / \mathrm{Ca}$ ratios in biogenic carbonates as tracers of increases in ocean stratification and trade wind weakening and/or collapse in the ETNP during ENSO episodes.

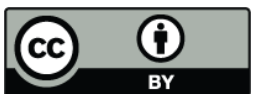

Correspondence to: J. D. Carriquiry (carriquiry@uabc.edu.mx)

\section{Introduction}

The El Niño - Southern Oscillation (ENSO) phenomenon is one of the main sources of global climate variability at interannual time scales. The region of the mouth of the Gulf of California is characterized by a strong response to ENSO activity. During the El Niño episodes, this area experiences sea-surface temperature anomalies of $4{ }^{\circ} \mathrm{C}$, a dramatic submergence of the thermocline down to $50 \mathrm{~m}$ from its normal depth, and a decrease in salinity (0.1-0.2 psu) that results from the invasion of tropical surface waters (Lavin and Marinone, 2003; Castro et al., 2006). Although the Gulf of California has been studied widely, the regional oceanographic anomalies produced by ENSO have only been derived from synoptic studies; hence, continuous long-term studies of oceanographic variability have been missing.

Corals offer significant advantages as paleoceanographic recorders because they contain annual skeletal growth bands that provide a very precise annual chronology. Their widespread presence throughout the tropical seas of the world, and the geochemical signals contained in their skeletons provide a powerful means of reconstructing environmental conditions with a fidelity that is comparable to instrumental records (Gagan et al., 2000). With regard to trace metals, it is now widely known that the ocean distribution of certain trace elements, such as cadmium (Cd) and manganese $(\mathrm{Mn})$, are sensitive to oceanographic processes such as vertical mixing, upwelling and lateral advection (Boyle et al., 1976; Landing and Bruland, 1980; Boyle, 1988; DelgadilloHinojosa et al., 2001). Because the distribution coefficient $(D)$ of $\mathrm{Cd} / \mathrm{Ca}$ and $\mathrm{Mn} / \mathrm{Ca}$ ratios in the coral relative to seawater is known (Shen and Sanford, 1990), their variation in the coral skeleton can provide us with detailed oceanographic records on different time scales.

Published by Copernicus Publications on behalf of the European Geosciences Union. 


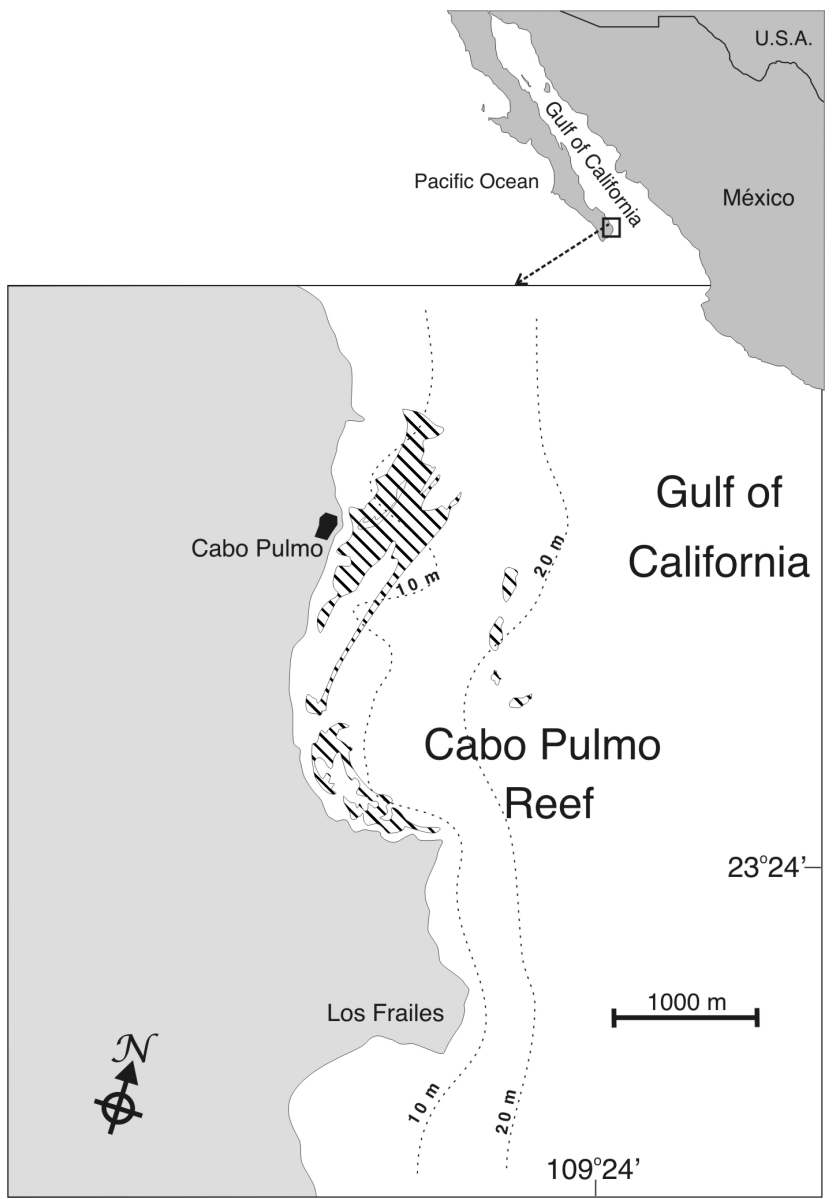

Fig. 1. Location of Cabo Pulmo reef (hatched area), at the mouth of the Gulf of California, Mexico.

Because of its geochemistry and nutrient-type distribution in the ocean, $\mathrm{Cd}$ is a direct tracer of upwelling and vertical mixing (Boyle et al., 1976; Boyle, 1988). During upwelling events, subsurface water rich in nutrients is carried to the surface exposing the reef areas to seawater enriched with $\mathrm{Cd}$, and corals are able to record these changes in their skeleton (Shen et al., 1987, 1992a; Linn et al., 1990; Delaney et al., 1993; Reuer et al., 2003). The variability of Cd in the coral skeleton has been correlated with large oceanographic processes, such as ENSO, that efficiently modulates upwelling activity in the eastern tropical Pacific (Shen et al., 1987, 1992a).

In a different way to cadmium, $\mathrm{Mn} / \mathrm{Ca}$ ratios have also been used to document changes in the dynamics of the ocean surface. In the Pacific Ocean, dissolved-Mn in the water column shows a subsurface maximum, due to dissolution of $\mathrm{Mn}$ oxides (Landing and Bruland, 1980; Nameroff et al., 2002). As in the Pacific Ocean, the vertical distribution of dissolved manganese in the southern Gulf of California shows a high concentration at the ocean's surface (from 2 to $7 \mathrm{nM}$, in the upper $50 \mathrm{~m}$ ), a rapid decrease in subsurficial waters (to
$<2 \mathrm{nM}$ ), probably due to oxidative removal and by adsorption of dissolved-Mn by suspended particles, and finally a slight increase in deep waters where the oxygen minimum zone occurs (Delgadillo-Hinojosa et al., 2006). The surface maximum of dissolved-Mn in the Gulf of California has been explained mainly by atmospheric supply of particulate $\mathrm{Mn}$ and by the photoreduction of manganese oxides (DelgadilloHinojosa et al., 2006). The potential supply of Mn by fluvial discharge into the Gulf of California is considered insignificant because most of the rivers that reach the Gulf of California have been damned, significantly reducing the flow of freshwater (e.g. Carriquiry et al., 2001).

Coral $\mathrm{Mn} / \mathrm{Ca}$ records have been shown to record periodic advective pulses of dissolved-Mn originating from the dissolution of Mn oxides that are present in the coastal shelf of the Galapagos Islands (Linn et al., 1990; Shen et al., 1991; Delaney et al., 1993). Also, but in a different manner, the ENSO variability has been documented in the $\mathrm{Mn} / \mathrm{Ca}$ ratios of corals from Tarawa atoll, in the central Pacific Ocean (Shen et al., 1992b). In this region, as a consequence of Trade wind reversal (development of intense Westerlies) that takes place during ENSO years, bottom lagoonal sediments become resuspended, enriching the water column with diagenetic-Mn; corals record these Mn-pulse events in their growth bands (Shen et al., 1992b).

Variation in the $\mathrm{Cd} / \mathrm{Ca}$ and $\mathrm{Mn} / \mathrm{Ca}$ ratios along the growth bands of corals seem to record oceanographic conditions that favor the $\mathrm{Cd}$ and $\mathrm{Mn}$ availability in the reef environment, but whether of these trace element ratios vary among species of corals in the same locality has rarely been assessed (Delaney et al., 1993; Reuer et al., 2003; Matthews et al., 2008). In this study, we examine the ratios of $\mathrm{Cd} / \mathrm{Ca}$ and $\mathrm{Mn} / \mathrm{Ca}$ in three species of massive corals (Pavona gigantea, Pavona clivosa and Porites panamensis) from Cabo Pulmo reef, Southern Gulf of California, Mexico, to assess oceanographic changes during ENSO events.

\section{Materials and methods}

\subsection{Characterization of the study area}

The Cabo Pulmo reef is located on the east coast of southern Baja California $\left(23^{\circ} 25^{\prime} \mathrm{N}, 109^{\circ} 25^{\prime} \mathrm{W}\right)$ (Fig. 1), inside Los Frailes Bay, at a water depth between 5 and $18 \mathrm{~m}$. The shallow reef flats are dominated by species of the branching coral Pocillopora, while in the deeper reef zones, species of massive corals thrive, such as Porites panamensis, Pavona gigantea and Pavona clivosa, and to a lesser extent Porites porosa, Tubastraea tenuilamellosa, Tubastrae coccinea, Psammocora stellata, Psammocora brighami and Madracis sp. (Reyes-Bonilla, 1993a). Structurally, the reef is composed of well-cemented conglomerate bars that have been exposed above the sea floor by differential erosion (Carriquiry, personal observation). Young coral reef development 
takes place on top of these conglomeratic bars, with a reef framework of up to $3 \mathrm{~m}$ thick in some locations (the average thickness is $\sim 1 \mathrm{~m}$ ). Although there is little hydrologic information for the area, during spring a thermocline develops at $\sim 10 \mathrm{~m}$ depth, while in summer, autumn and winter, the water column from 0 to $30 \mathrm{~m}$ is well mixed. SST varies between 19 and $30^{\circ} \mathrm{C}$, but occasionally is lower than this during the upwelling period (see Fig. 2) causing sporadic coldwater bleaching events (e.g., Reyes-Bonilla, 1993b).

In the absence of any physical barrier that could separate Cabo Pulmo reef from the open ocean, and the lack of a continental shelf in the area, the hydrological characteristics in the reef are the same as to those of the Gulf of California. Geographically, the reef site is located in the Eastern Tropical North Pacific (ETNP) in a hydrographic region known as Transitional Pacific of Mexico. The oceanography of the area is complex because it is affected by the large-scale circulation of the Eastern Tropical Pacific. This region seasonally receives the arrival of the cold $\left(18-20^{\circ} \mathrm{C}\right)$ and low salinity $(<34.5 \mathrm{psu})$ water of the California Current $(\mathrm{CCW})$, the saline water ( $>34.9 \mathrm{psu}$ ) of the Gulf of California water (GCW) and the water of the Coastal Current of Costa Rica (CCCRW) that later turns into the West Mexican Current (WMC) transporting equatorial waters of low-salinity (34 to $34.8 \mathrm{psu}$ ) and higher temperature $>25^{\circ} \mathrm{C}$ (e.g. Castro et al., 2006) into the mouth of the Gulf of California. The interannual climatic and oceanographic variability in this region is modulated by El Niño events that significantly affect the circulation patterns in the ETNP (Baumgartner and Christensen, 1985; Lavin and Marinone, 2003; Castro et al., 2006). Although the normal seasonal SST cycle in this region shows an $8^{\circ} \mathrm{C}$ range, during the El Niño years there have been positive SST anomalies of $3-4{ }^{\circ} \mathrm{C}$ (Castro et al., 2006). This anomalous warming associated with ENSO episodes produces a deepening of the thermocline, which significantly limits the supply of nutrients to the surface and their availability for primary organic productivity. This situation adversely affects coastal fisheries in northwest Mexico, where the major fisheries in the Mexican Pacific take place (Lluch-Cota et al., 1999).

\subsection{Sample collection}

Live colonies of Pavona gigantea (227 mm high), Pavona clivosa $(225 \mathrm{~mm}$ high) and Porites panamensis $(154 \mathrm{~mm}$ high) were collected at water depths between 5 and $10 \mathrm{~m}$ from Cabo Pulmo reef, in May 1990. In the laboratory, the corals were submerged in $50 \%(\mathrm{v} / \mathrm{v})$ sodium hypochlorite to remove the organic tissue. The coral colonies were slabbed using a circular saw (MK Diamond Products, Inc.) equipped with a $14^{\prime \prime}$ diameter diamond blade. The resulting $7 \mathrm{~mm}$ thick coral slabs were x-rayed (Picker X-ray G850S) to reveal the annual growth bands that were used to develop the age model of each coral colony. From the positive impressions of $\mathrm{x}$-ray images, each annual growth band was traced

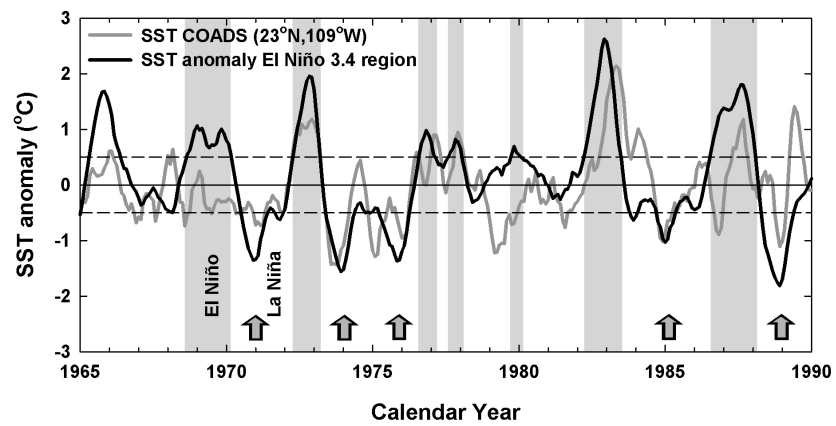

Fig. 2. Comparison of temperature anomalies in the Niño 3.4 region, filtered by a 5-month moving average that define the variability of El Niño (Trenberth, 1997) versus the temperature anomalies (same filtering) in the mouth of the Gulf of California obtained from the COADS database (resolution of $2^{\circ} \times 2^{\circ}$, Slutz et al., 1985). The gray bars define the timing and duration (months) of the El Niño events and the arrows indicate the cold events of La Niña defined by Trentberth (1997).

using acetate sheets over the positive prints. The annual skeletal growth rates were calculated from three different transects in each $\mathrm{x}$-rayed coral colony. The observed growth rates were: $11.3 \pm 2.3 \mathrm{~mm} /$ year (1970-1989) for Pavona gigantea; $9.76 \pm 2.5 \mathrm{~mm} / \mathrm{year}$ (1967-1989) for Pavona clivosa, and $6.67 \pm 1.1 \mathrm{~mm} / \mathrm{year}$ (1967-1989) for Porites panamensis. The annual growth bands traced on the acetate sheets were transferred to the coral slabs to later cut each annual growth band using a mini-drill (Dremel, Moto-Tool 395) equipped with a flexible shaft (Dremel 225T1) and a circular mini-saw (Dremel 409). Prior to sample treatment and analyses, coral samples were crushed in an agate mortar to a size range of $250-600 \mu \mathrm{m}$.

\subsection{Sample treatment and analyses}

Analyses of the $\mathrm{Cd} / \mathrm{Ca}$ and $\mathrm{Mg} / \mathrm{Ca}$ ratios in the coral skeleton was performed using the Shen and Boyle (1988) method, with the modifications proposed by Linn et al. (1990). This procedure uses a sequence of successive oxidative and reductive steps designed to remove the metals adsorbed to the surface of coral, the metals associated with Fe- and Mn-oxides, and the metals incorporated into the organic matter fraction commonly present in the skeletons. The final step includes coprecipitation with an ammonium pyrrolidine dithiocarbamate (APDC) and Co complex, aimed at removing excess-Ca in the solution and to concentrate the metals. This procedure is designed to only measure the metals that are part of the crystal lattice of the calcium carbonate coral skeleton. The analysis of $\mathrm{Cd}$ and $\mathrm{Mn}$ was performed in an atomic absorption spectrophotometer, Thermo Jarrell Ash (TJA), SH12 model, equipped with a graphite furnace CTF-188 and a correction system developed by Smith-Hieftje. The Ca concentration of each sample was obtained from an aliquot of $40 \mu \mathrm{L}$ obtained prior to co-precipitation and diluted in $50 \mathrm{~mL}$ of 


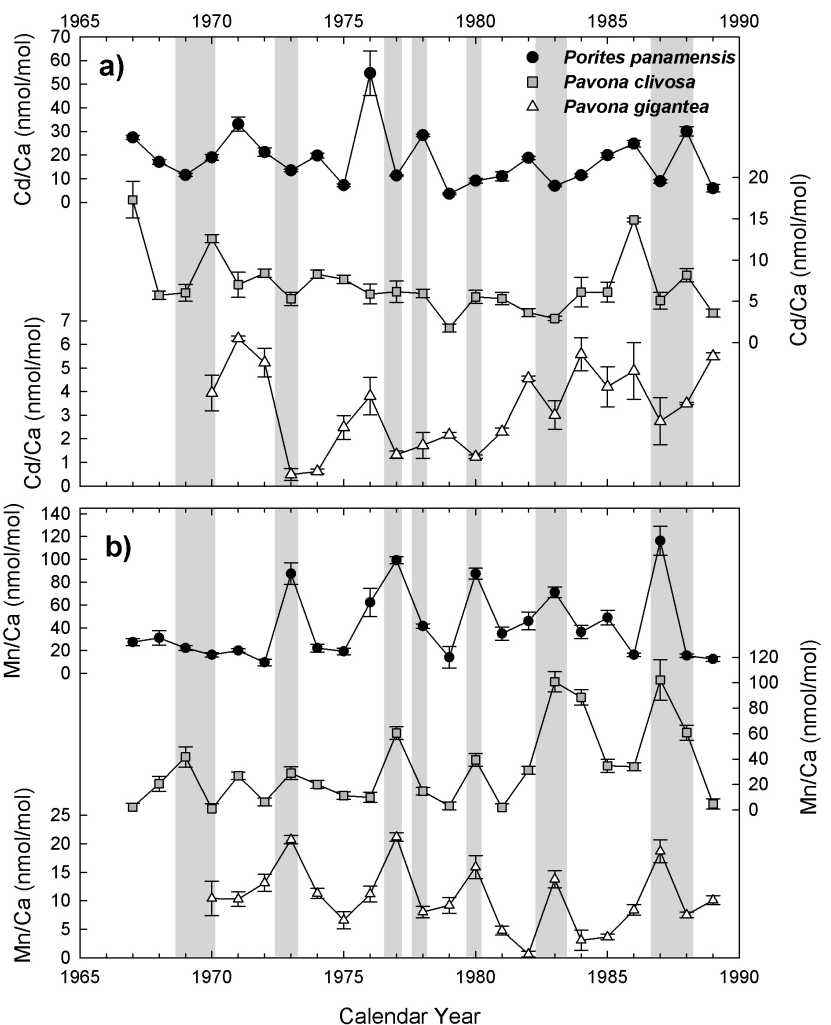

Fig. 3. Temporal variation (1967 to 1989 ) of the annual $\mathrm{Cd} / \mathrm{Ca}$ ratios of the three coral species used in this study (a), and temporal variation of the $\mathrm{Mn} / \mathrm{Ca}$ ratio in the skeleton of the same coral species (b). The error bars ( \pm 1 s.d.) were obtained from the replicates $(n=3)$ used to calculate the annual average. The gray bars define the timing and duration (months) of the El Niño events and the arrows indicate the cold events of La Niña defined by Trentberth (1997).

nitric acid $2 \mathrm{M}$. The solution was analyzed by atomic absorption using a nitrous oxide/acetylene flame. For quality control, a laboratory standard was prepared from a coral powder homogenate that was treated and analyzed in the same way as the samples. The calculated recovery percentage of the coral standard, spiked with $\mathrm{Cd}$ and $\mathrm{Mn}$ was $\pm 91 \%$ (the $\mathrm{Cd} / \mathrm{Ca}$ and $\mathrm{Mn} / \mathrm{Ca}$ data were corrected by the recovery). The calculated precision of the method was better than $10 \%(n=16)$.

\subsection{Oceanographic characteristics}

The average SST range in the Cabo Pulmo region is $\sim 8^{\circ} \mathrm{C}$, varying from $21.0^{\circ} \mathrm{C}$ in March to $28.5^{\circ} \mathrm{C}$ in September. At interannual time scales, SST variability at the mouth of the Gulf of California is controlled by El Niño. Figure 2 compares the SST-anomaly in the mouth of the Gulf of California region (MGC) $\left(2 \times 2\right.$ degrees resolution centered at $109^{\circ} \mathrm{W}$, $23^{\circ} \mathrm{N}$; COADS database, Slutz et al., 1985) with the SST anomalies observed in the Niño 3.4 region (Trenberth, 1997). With the exception of the moderate El Niño event of 1969 and the weak El Niño of 1980, the rest of the El Niño events in the 1965 to 1990 period (i.e., ENSO years 1972-1973, 1976 and 1977, 1982-1983 and 1986-1988) were characterized in this region by a significant positive anomaly in SST. SST anomalies between the two regions were synchronous, with the exception of the El Niño event of 1982-1983, where the thermal response in the mouth of the Gulf of California was of similar intensity but delayed by $\sim 3$ months (Fig. 2).

\section{Results and discussion}

\subsection{Interspecific differences in the $\mathrm{Cd} / \mathrm{Ca}$ and $\mathrm{Mn} / \mathrm{Ca}$ ratios of corals}

The skeletal ratio of $\mathrm{Cd} / \mathrm{Ca}(\mathrm{nmol} / \mathrm{mol})$ displayed significant variation among the three coral species studied (Table 1 and Fig. 3a). The mean $\mathrm{Cd} / \mathrm{Ca}$ ratio ( \pm 1 s.d.) increased from the coral Pavona gigantea (3.28 \pm 1.73 ) to Pavona clivosa

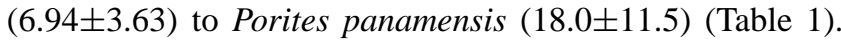
Furthermore, the average $\mathrm{Cd} / \mathrm{Ca}$ ratio $(2.76 \pm 1.51)$ in the coral Pavona gigantea sampled at seasonal resolution was similar to average $\mathrm{Cd} / \mathrm{Ca}$ ratios sampled at annual resolution, indicating that the annual resolution adequately reflects the incorporation of $\mathrm{Cd}$ in this species throughout the year.

Similar to the $\mathrm{Cd} / \mathrm{Ca}$ ratio, the $\mathrm{Mn} / \mathrm{Ca}$ ratio $(\mathrm{nmol} / \mathrm{mol})$ showed marked differences between species, but variability within each species (i.e., the relative standard deviation) was higher than in the $\mathrm{Cd} / \mathrm{Ca}$ ratio (Table 1 and Fig. 3b). The $\mathrm{Mn} / \mathrm{Ca}$ ratio among the different species increased in the same order as observed for the $\mathrm{Cd} / \mathrm{Ca}$ ratio: the $\mathrm{Mn} / \mathrm{Ca}$ ratio was lowest in Pavona gigantea $(10.45 \pm 5.63)$, moderate in Pavona clivosa (32.3 \pm 31.0$)$, and highest in Porites panamensis (41.6 \pm 31$)$. Also, similar to the $\mathrm{Cd} / \mathrm{Ca}$ ratio, the average $\mathrm{Mn} / \mathrm{Ca}$ ratio sampled at seasonal resolution (10.61 \pm 8.9$)$ was practically equal to that measured at annual resolution (Table 1).

Concentration differences of several geochemical proxies have also been described from different coral species growing in the same locality, such as $\delta^{18} \mathrm{O}, \delta^{13} \mathrm{C}$ and $\mathrm{Sr} / \mathrm{Ca}$ ratios (de Villiers et al., 1994; Wellington et al., 1996; Grottoli and Wellington; 1999). However, the lack of information about $\mathrm{Cd} / \mathrm{Ca}$ and $\mathrm{Mn} / \mathrm{Ca}$ ratios among different coral species makes it difficult to interpret the observed interspecific geochemical differences of this study. For instance, it has been shown that the $\mathrm{Cd} / \mathrm{Ca}$ ratios in the Caribbean coral Siderastrea siderea are greater than those measured in Montastrea annularis collected at the same site (Reuer et al., 2003). In the Pacific, Shen and Sanford (1990) found that the Cd/Ca ratio in Pavona clavus from the Galapagos was slightly lower than that measured in Pavona gigantea from Panama and concluded that these differences were caused by locality differences. Matthews et al. (2008) found that the $\mathrm{Cd} / \mathrm{Ca}$ ratio was highest in Pavona gigantean, moderate in Pavona clavus, and low in Porites lobata from the same locality, 
Table 1. Average ( \pm 1 s.d.) of the growth rate (GR mm/yr) and the $\mathrm{Cd} / \mathrm{Ca}$ and $\mathrm{Mn} / \mathrm{Ca}$ ratios (nmol/mol) measured in the corals collected from Cabo Pulmo reef, Gulf of California, Mexico.

\begin{tabular}{lccc}
\hline Coral & $\mathrm{GR}(\mathrm{mm} / \mathrm{yr})$ & $\mathrm{Cd} / \mathrm{Ca}$ & $\mathrm{Mn} / \mathrm{Ca}$ \\
\hline Pavona gigantea & $11.28 \pm 2.34$ & $3.28 \pm 1.73$ & $10.45 \pm 5.63$ \\
Pavona clivosa & $9.76 \pm 2.42$ & $6.94 \pm 3.63$ & $32.34 \pm 31.02$ \\
Porites panamensis & $6.68 \pm 1.06$ & $18.00 \pm 11.54$ & $41.64 \pm 31.01$ \\
Pavona gigantea (seasonal sampling) & $11.40 \pm 2.28$ & $2.76 \pm 1.51$ & $10.61 \pm 8.90$ \\
\hline
\end{tabular}
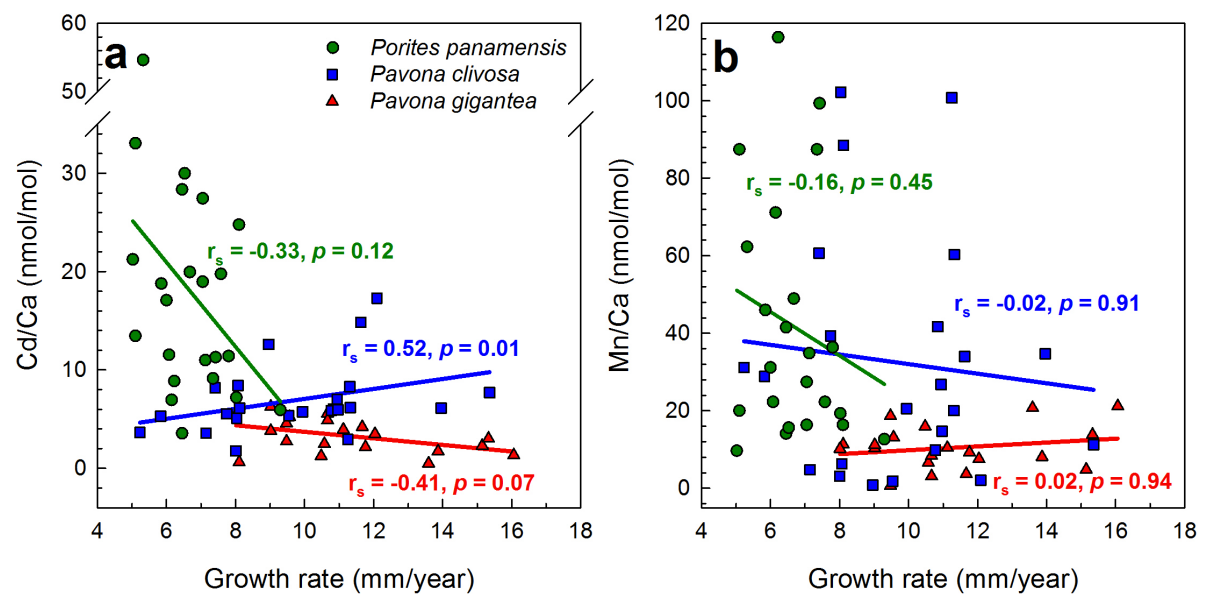

Fig. 4. Relationship between skeletal growth rate and $\mathrm{Cd} / \mathrm{Ca}$ (a) and $\mathrm{Mg} / \mathrm{Ca}$ (b) for Porites panamensis, Pavona clivosa and Pavona gigantea . Spearman rank correlation value $\left(r_{\mathrm{S}}\right)$ and statistical probability $(p)$ are provided.

and they proposed three possible explanations for the differences: (1) differences in the plankton feeding rate (heterotrophy), (2) kinetic effects controlled by the differences in growth rate, and (3) an artifact related to the cleaning procedure. The authors did not find a relationship between growth rate and the $\mathrm{Cd} / \mathrm{Ca}$ ratio, nor an effect due to heterotrophy; concluding that, in their study, sample treatment effects explained the species' differences. According to these authors, the skeletal structure of Porites is more delicate relative to that of Pavona, favoring a larger loss of Porites samples in their procedures; the losses they observed could explain the differences in the $\mathrm{Cd} / \mathrm{Ca}$ ratios among species. We did not measured the sample loss among species, but our results indicate that in the Gulf of California, corals of the genus Porites concentrate more $\mathrm{Cd}$ and $\mathrm{Mn}$, compared with species of the genus Pavona. This result the opposite conclusion reached for the Gulf of Panama (Mattehws et al., 2008). Consequently, it is highly unlikely that a larger sample loss during the cleaning protocol of Porites samples could explain why Porites had higher $\mathrm{Cd} / \mathrm{Ca}$ and $\mathrm{Mn} / \mathrm{Ca}$ ratios than the two species of Pavona studied here.

Because corals potentially bioconcentrate metals from their diets (Fallon et al., 2002), the feeding preferences among species could also explain the differences in metal uptake. For instance, it has been found that heterotrophic feeding by Porites is similar or slightly greater than that Pavona (e.g. Matthews et al., 2008). Thus, the contrast in heterotrophic feeding among the studied species, if it exists, would have to explain the remarkable 4.5 fold increase in the $\mathrm{Cd} / \mathrm{Ca}$ ratio and 4 fold increase for the $\mathrm{Mn} / \mathrm{Ca}$ ratio between the lowest and highest ratios (Table 1), which seems unlikely to us.

Concerning the effects of growth rate on metal uptake, we found that, except for the significant correlation between the $\mathrm{Cd} / \mathrm{Ca}$ ratios and the skeletal growth rate of Pavona (Spearman rank correlation, $r_{\mathrm{s}}=0.52, p=0.012$ ), other coral species showed no relationship between growth rate and $\mathrm{Cd} / \mathrm{Ca}$ and $\mathrm{Mn} / \mathrm{Ca}$ ratios (Fig. 4). The effect of coral growth rate has been assessed elsewhere through the $\mathrm{Sr} / \mathrm{Ca}$ ratio, with contradictory results. For instance, de Villiers et al. $(1994,1995)$ found that high values of the $\mathrm{Sr} / \mathrm{Ca}$ ratio in the coral skeleton of Pavona clavus were associated with lower skeletal growth rates. High $\mathrm{Sr} / \mathrm{Ca}$ ratios in the coral Diploria labyrinthiformis from Bermuda were inversely correlated with low temperatures and low rates of skeletal growth, and vice versa (Goodkin et al., 2005). In contrast, Allison and Finch (2004) found that the growth rate of Porites lobata did not affect the rate of incorporation of $\mathrm{Sr}$ in the coral skeleton. Interestingly, these studies were conducted on one coral colony along two sampling transects with different growth rates, and 
Table 2. Distribution coefficients $(D)$ calculated $( \pm 1$ s.d.) for the $\mathrm{Cd} / \mathrm{Ca}$ and $\mathrm{Mn} / \mathrm{Ca}$ ratios of the coral species studied, considering the average $\mathrm{Cd}$ and $\mathrm{Mn}$ concentration in the surface layer of the southern Gulf of California (station 19, Delgadillo-Hinojosa et al., 2001, 2006) and the average Ca concentration in seawater (of $10.3 \mathrm{mM}$, Bruland, 1983).

\begin{tabular}{lcc}
\hline Coral species/(Me/Ca) ratio & Calculated $D( \pm 1$ s.d.) & Estimated $D$ (Shen et al., 1993) \\
\hline Porites panamensis & & \\
$\mathrm{Cd} / \mathrm{Ca}$ & $0.83 \pm 0.53$ & $0.9-2.0$ \\
$\mathrm{Mn} / \mathrm{Ca}$ & $0.13 \pm 0.10$ & \\
Pavona clivosa & & \\
$\mathrm{Cd} / \mathrm{Ca}$ & $0.32 \pm 0.17$ & \\
$\mathrm{Mn} / \mathrm{Ca}$ & $0.10 \pm 0.10$ & \\
Pavona gigantea & & \\
$\mathrm{Cd} / \mathrm{Ca}$ & $0.15 \pm 0.08$ & \\
$\mathrm{Mn} / \mathrm{Ca}$ & $0.03 \pm 0.02$ & \\
\hline
\end{tabular}

Table 3. Comparison between average ( \pm 1 s.d.) $\mathrm{Cd} / \mathrm{Ca}$ and $\mathrm{Mn} / \mathrm{Ca}$ ratios (nmol/mol) for ENSO and non-ENSO years in corals collected from Cabo Pulmo reef. The probability values of the two sample student's t-tests are included. The trace metal ratios for the years that are statistically different $(p \leq 0.05)$ between ENSO and non-ENSO conditions are marked in bold.

\begin{tabular}{llcc}
\hline Coral & ENSO vs. Non-ENSO & $\mathrm{Cd} / \mathrm{Ca}$ & $\mathrm{Mn} / \mathrm{Ca}$ \\
\hline Pavona gigantea & ENSO $(n=7)$ & $\mathbf{2 . 0 1} \pm \mathbf{1 . 1 0}$ & $\mathbf{1 5 . 1 4} \pm \mathbf{5 . 6 4}$ \\
& Non-ENSO $(n=13)$ & $\mathbf{3 . 9 6} \pm \mathbf{1 . 6 4}$ & $\mathbf{7 . 9 3} \pm \mathbf{3 . 8 1}$ \\
& Probability $(p)$ & $\mathbf{0 . 0 0 2 8}$ & $\mathbf{0 . 0 0 7 0}$ \\
Pavona clivosa & ENSO $(n=9)$ & $6.42 \pm 2.68$ & $\mathbf{4 9 . 3 7} \pm \mathbf{3 5 . 6 7}$ \\
& Non-ENSO $(n=14)$ & $7.27 \pm 4.19$ & $\mathbf{2 1 . 3 9} \pm \mathbf{2 2 . 7 1}$ \\
& Probability $(p)$ & 0.2783 & $\mathbf{0 . 0 2 8 8}$ \\
Porites panamensis & ENSO $(n=9)$ & $18.30 \pm 15.31$ & $\mathbf{6 4 . 2 0} \pm \mathbf{3 7 . 9 1}$ \\
& Non-ENSO $(n=14)$ & $17.81 \pm 8.99$ & $\mathbf{2 7 . 1 4} \pm \mathbf{1 2 . 8 1}$ \\
& Probability $(p)$ & 0.4661 & $\mathbf{0 . 0 0 9 7}$ \\
\hline
\end{tabular}

the contrasting results of these studies illustrate differences in response among the coral species and localities.

Independent of the factors controlling $\mathrm{Cd} / \mathrm{Ca}$ and $\mathrm{Mn} / \mathrm{Ca}$ ratios in the coral skeleton, the results obtained in this study indicate differences in the distribution coefficients $(D)$ among the species. Using the average dissolved $\mathrm{Cd}$ concentration $(0.22 \mathrm{nM})$ and dissolved $\mathrm{Mn}(3.34 \mathrm{nM})$ in the surface ocean of the southern Gulf of California (DelgadilloHinojosa et al., 2001, 2006) and the ocean average Ca concentration (10.3 mM, Bruland, 1983), we calculated the distribution coefficients for $\mathrm{Cd}$ and $\mathrm{Mn}$ of the different species studied (Table 3). These results show that the distribution coefficient for $\mathrm{Mn}$ and $\mathrm{Cd}$ in Porites panamensis and the $D_{\mathrm{Cd}}$ for Pavona clivosa are within the ranges published by Shen (1993), while the distribution coefficient values for $\mathrm{Cd}$ in Pavona clivosa, and for $\mathrm{Cd}$ and $\mathrm{Mn}$ in Pavona gigantea are smaller than the previously estimated ones (Table 3). Because of the analytical difficulties involved in measuring extremely low concentrations of $\mathrm{Cd}$ and $\mathrm{Mn}$, in both coral skeleton and seawater, very few studies have attempted to calculate $D$ of $\mathrm{Cd}$ and $\mathrm{Mn}$ in different coral species (Shen and Sanford, 1990; Shen, 1993). Consequently, the range of $D$ for several coral species, like Pavona gigantea, is still unknown. The results of this study suggest that the factors that ultimately determine the concentration of $\mathrm{Mn}$ and $\mathrm{Cd}$ in the coral skeletons remain somewhat elusive.

\subsection{Interannual variations of the $\mathrm{Cd} / \mathrm{Ca}$ and $\mathrm{Mn} / \mathrm{Ca}$ ra- tio and ENSO}

The annually-resolved $\mathrm{Cd} / \mathrm{Ca}$ and $\mathrm{Mn} / \mathrm{Ca}$ ratios obtained from coral skeletons from the Gulf of California showed significant interannual variability. The $\mathrm{Cd} / \mathrm{Ca}$ and $\mathrm{Mn} / \mathrm{Ca}$ variability during the 1967-1989 period for the three coral species is shown in Fig. 3, and the normalized anomalies of the average $\mathrm{Cd} / \mathrm{Ca}$ and $\mathrm{Mn} / \mathrm{Ca}$ ratios are shown in Fig. 5. The ratios indicate a clear influence of ENSO events, although the average normalized anomalies of the three coral species show that the effect is more evident in the $\mathrm{Mn} / \mathrm{Ca}$ ratio than in the $\mathrm{Cd} / \mathrm{Ca}$ ratio. This can be better observed by separating the $\mathrm{Cd} / \mathrm{Ca}$ and $\mathrm{Mn} / \mathrm{Ca}$ ratios between ENSO and Non-ENSO years (Table 2 and Fig. 6). Statistical student's 

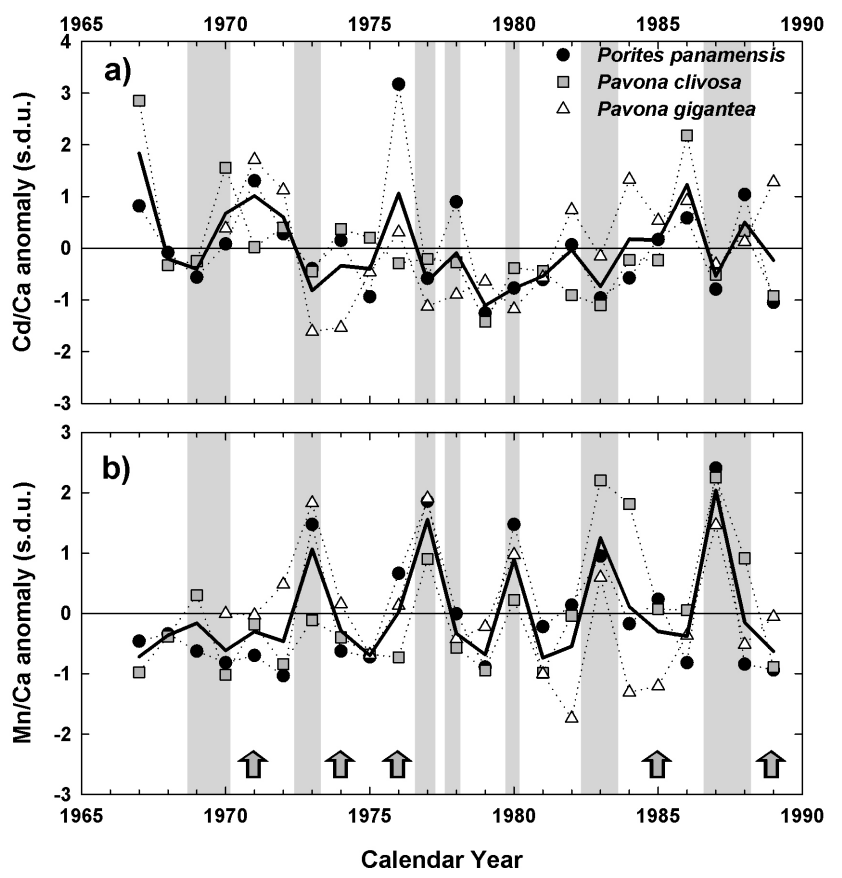

Fig. 5. Temporal variation for the 1967-1990 period of the normalized anomalies in standard deviation units (s.d.u.) of the $\mathrm{Cd} / \mathrm{Ca}$ ratio in three species of corals studied (a) and temporal variation of the normalized anomalies (s.d.u.) of the $\mathrm{Mn} / \mathrm{Ca}$ ratio (b). The solid line represents the average anomalies for both trace metal ratios. The gray bars define the timing and duration (months) of the El Niño events and the arrows indicate the cold events of La Niña defined by Trentberth (1997).

t-tests indicate that, with the exception of Pavona gigantea, wich showed significantly lower $\mathrm{Cd} / \mathrm{Ca}$ ratios during ENSO years $(p<0.05)$ compared with Non-ENSO years, the average $\mathrm{Cd} / \mathrm{Ca}$ ratio of Pavona clivosa and Porites panamensis did not vary significantly between the two climatic conditions (Table 2 and Fig. 6). In contrast to the $\mathrm{Cd} / \mathrm{Ca}$ ratio, the $\mathrm{Mn} / \mathrm{Ca}$ ratio was significantly higher $(p<0.05)$ during ENSO events, compared to the Non-ENSO years, in the three coral species (Table 2 and Fig. 6).

The $\mathrm{Cd} / \mathrm{Ca}$ and $\mathrm{Mn} / \mathrm{Ca}$ ratios that were analyzed at seasonal resolution in the Pavona gigantea (Fig. 7) showed variability associated with ENSO, that was similar to the annual $\mathrm{Cd} / \mathrm{Ca}$ and $\mathrm{Mn} / \mathrm{Ca}$ ratios (Fig. 3). Similarly to the annual $\mathrm{Cd} / \mathrm{Ca}$ records, the variability of the $\mathrm{Cd} / \mathrm{Ca}$ sampled at seasonal resolution in Pavona gigantea was less responsive to ENSO events (Fig. 7). In contrast, the seasonal and annual $\mathrm{Mn} / \mathrm{Ca}$ ratios in Pavona gigantea showed a clear increase during ENSO events. It is interesting to note from the seasonal-resolution record that the maximum $\mathrm{Mn} / \mathrm{Ca}$ values occured during the final phase of the El Niño warming events, particularly during the El Niño events of 1972-1973, 1980-1981, 1982-1983 (Fig. 7). This apparent delay in the response of the seasonal $\mathrm{Mn} / \mathrm{Ca}$ series indicates that the hy-
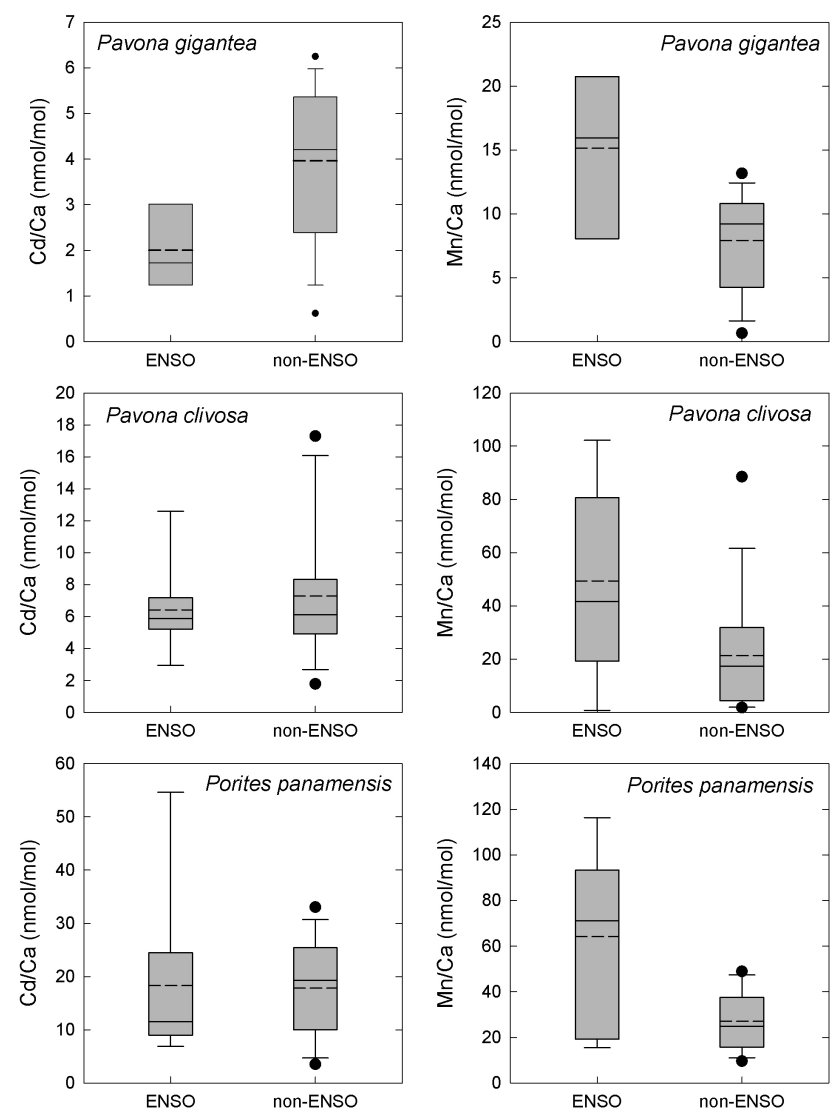

Fig. 6. Box plot separating the $\mathrm{Cd} / \mathrm{Ca}$ and $\mathrm{Mn} / \mathrm{Ca}$ ratios between ENSO and Non-ENSO years. The solid line and dashed lines inside the box shows the median and the mean of the distribution, respectively.

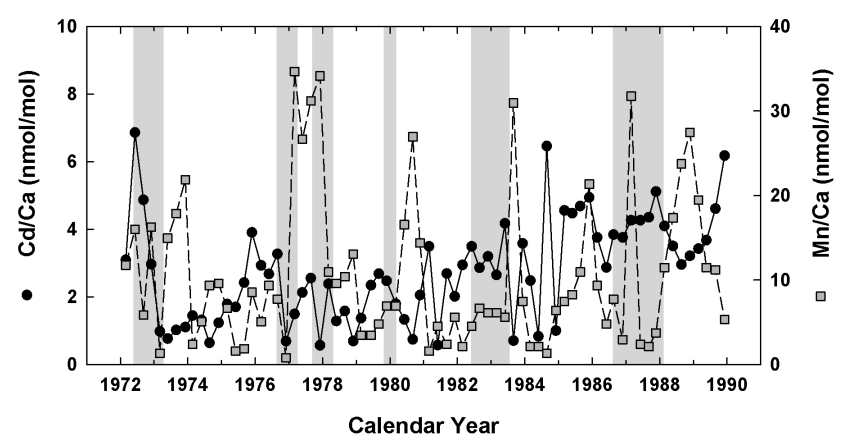

Fig. 7. Seasonal variation of the $\mathrm{Cd} / \mathrm{Ca}$ ratio in Pavona gigantea for the 1972-1990 period (a) and seasonal variation of the $\mathrm{Mn} / \mathrm{Ca}$ ratio in the same coral (b).

drographic conditions that favor an increase in dissolved $\mathrm{Mn}$ concentration in the surface waters of the Gulf of California occur shortly after the El Niño reaches its mature phase of maximum warming.

In accordance with Boyle et al. (1976), Boyle (1988), Landing and Bruland (1980), Johnson et al. (1996), and 
Nameroff et al. (2002), biogeochemical studies in the Gulf of California suggest that the vertical distribution of dissolved $\mathrm{Cd}$ depends mainly on two processes: the seasonal cycle of nutrients and organic matter (Delgadillo-Hinojosa et al., 2001). In contrast to $\mathrm{Cd}$, the behavior of dissolved Mn appears to be controlled by physical processes such as atmospheric input, photo-reduction of manganese oxides in the surface water, which releases Mn from the particles to the dissolved phase, and the dissolution of Mn oxides in the oxygen minimum zone below $\sim 400 \mathrm{~m}$ water depth (DelgadilloHinojosa et al., 2006).

The increase of $\mathrm{Cd}$ in surface waters is generally controlled by vertical mixing. In the southern Gulf of California this process depends entirely on the seasonal upwelling, whereas in the central Gulf, it is caused by year-round turbulent mixing (Delgadillo-Hinojosa et al., 2001). In contrast, atmospheric input of Mn to the surface waters of the Gulf may be relatively constant throughout the year. The magnitude of the Mn contribution may change due to seasonal changes in wind direction and interannual changes in the direction and intensity of winds associated with the onset of ENSO (Delgadillo-Hinojosa et al., 2006). Changing wind patterns would alter the transport of particulate $\mathrm{Mn}$ to the surface waters of the Gulf, decreasing the concentration of dissolved $\mathrm{Mn}$ and consequently the incorporation of $\mathrm{Mn}$ in coral skeletons. In addition, increased vertical mixing, which would increase the concentration of dissolved $\mathrm{Cd}$ in surface waters, may in turn dilute the dissolved Mn at the surface.

These different scenarios may partially explain differences in the oceanic behavior of both elements, as well as the changes in surface availability of $\mathrm{Cd}$ and $\mathrm{Mn}$ under ENSO vs non-ENSO conditions. The interannual variations in coral $\mathrm{Cd} / \mathrm{Ca}$ and $\mathrm{Mn} / \mathrm{Ca}$ ratios show clear evidence that the incorporation of $\mathrm{Cd}$ and $\mathrm{Mn}$ in coral skeleton is influenced by ENSO conditions, but the intake of each metal is controlled by different process. The decrease in the incorporation of $\mathrm{Cd}$ and the marked increase in $\mathrm{Mn}$ during the mature phase of El Niño (Fig. 5) suggest strongly reduced vertical mixing in the Gulf of California. SST data for the area near the mouth of the Gulf of California (obtained from COADS, $2^{\circ} \times 2^{\circ}$ resolution, centered at $23^{\circ} \mathrm{N}, 109^{\circ} \mathrm{W}$ ) show temperature anomalies of $\sim 2{ }^{\circ} \mathrm{C}$ (Fig. 2) during El Niño events. Notwithstanding, in situ measurements of temperature during El Niño warming can reach $>4{ }^{\circ} \mathrm{C}$ in this region (Castro et al., 2000).

Oceanic warming during El Niño events produces a relaxation of upwelling and a stabilization of the thermocline (e.g., Lluch-Cota, 2000; Kahru et al., 2004), which acts as a physical barrier to intake of $\mathrm{Cd}$ from deeper waters into the surface layer (Delgadillo-Hinojosa et al., 2001; Dominguez-Rosas, 2008). In turn, this process increases the residence time of particulate-Mn in surface waters, allowing an increase in the photo-reduction of particulate-Mn and the release of the available $\mathrm{Mn}$ into the dissolved phase (Delgadillo-Hinojosa et al., 2006; Diaz-Rodriguez, 2008).
When comparing upwelling periods (non-ENSO conditions) with non-upwelling periods (ENSO conditions), the behavior of the coral $\mathrm{Cd} / \mathrm{Ca}$ ratios in the Gulf of California is similar to that observed in the Gulf of Panama (Matthews et al., 2008). Moreover, Pavona gigantea was the most sensitive to changes in the availability of Cd between ENSO and non-ENSO conditions.

In contrast to the $\mathrm{Cd} / \mathrm{Ca}$, the $\mathrm{Mn} / \mathrm{Ca}$ ratio showed a significant increase during ENSO years in the three species of corals. This result indicates that in the Gulf of California the $\mathrm{Mn} / \mathrm{Ca}$ ratio in coral is a better indicator of oceanographic changes generated by the El Niño phenomenon. Several studies suggest that the $\mathrm{Mn} / \mathrm{Ca}$ ratios in corals can be used as an "indirect" tracers of ENSO events in the Galapagos Islands (Linn et al., 1990; Shen and Sanford, 1990; Shen et al., 1991; Delaney et al., 1993). The results of this study indicate that coral $\mathrm{Mn} / \mathrm{Ca}$ ratios also provide a clear ENSO signal in the mouth of the Gulf of California.

\section{Conclusions}

The $\mathrm{Cd} / \mathrm{Ca}$ and $\mathrm{Mn} / \mathrm{Ca}$ ratios in the corals Pavona clivosa, Porites panamensis and Pavona gigantea display clear evidence of El Niño activity at the mouth of the Gulf of California, although the effect is stronger in the $\mathrm{Mn} / \mathrm{Ca}$ than in the $\mathrm{Cd} / \mathrm{Ca}$ ratios. The seasonal-resolution $\mathrm{Cd} / \mathrm{Ca}$ and $\mathrm{Mn} / \mathrm{Ca}$ ratios in Pavona gigantea showed interannual variability related to ENSO that was very similar to that observed in the annually-resolved records. $\mathrm{Mn} / \mathrm{Ca}$ values were highest at the end of the warming phase of El Niño episodes, indicating that the oceanographic conditions that increase the concentration of dissolved Mn develop immediately after the El Niño warming event reaches its mature phase. Our results show that in the Gulf of California, the $\mathrm{Mn} / \mathrm{Ca}$ ratio in corals reflects better the oceanographic changes generated by ENSO activity than $\mathrm{Cd} / \mathrm{Ca}$ ratios.

The average $\mathrm{Cd} / \mathrm{Ca}$ and $\mathrm{Mn} / \mathrm{Ca}$ ratios were greatest in Porites panamensis and lowest in Pavona gigantea. The seasonal records of $\mathrm{Cd} / \mathrm{Ca}$ and $\mathrm{Mn} / \mathrm{Ca}$ ratios in Pavona gigantea were similar to the annually-resolved records, suggesting that an annual sampling resolution adequately reflects the variability of these elemental ratios through the year. No evidence was found to support recent suggestions that the incorporation of $\mathrm{Cd}$ and $\mathrm{Mn}$ in the coral skeletons is affected by sample treatment, heterotrophic feeding rates, or by skeletal growth rate. However, the distribution coefficients of $\mathrm{Cd}\left(D_{\mathrm{Cd}}\right)$ and $\mathrm{Mn}\left(D_{\mathrm{Mn}}\right)$ varied among the coral species. The $D_{\mathrm{Cd}}$ and $D_{\mathrm{Mn}}$ in Porites panamensis, and $D_{\mathrm{Cd}}$ for Pavona clivosa, were within the published ranges. The $D_{\mathrm{Cd}}$ in Pavona clivosa, and $D_{\mathrm{Cd}}$ and $D_{\mathrm{Mn}}$ in Pavona gigantea were smaller than previous estimates, suggesting that more factors may control $D$ in the coral skeletons than previously thought. 
Acknowledgements. We want to greatly thank Cathy Withlock for the superb editorial handling and support. Her contributions greatly enhanced this manuscript. We also thank Pedro G. Castro and Fernando Soto for their support in the lab. This work was financially supported by CONACYT and UABC, Mexico.

Edited by: C. Whitlock

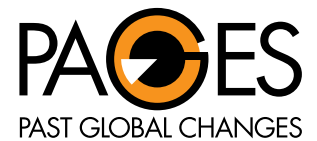

The publication of this article was sponsored by PAGES.

\section{References}

Allison, N. and Finch, A. A.: High-resolution Sr/Ca records in modern Porites lobata corals: effects of skeletal extension rate and architecture, Geochem. Geophys. Geosyst., 5, Q05001, doi:10.1029/2004GC000696, 2004.

Baumgartner, T. R. and Christensen Jr., N.: Coupling of the Gulf of California to large-scale interannual climatic variability, J. Mar. Res., 43, 825-848, 1985.

Boyle, E. A.: Cadmium: chemical tracer of deepwater paleoceanography, Paleoceanography 3, b471-489, 1988.

Boyle, E. A., Scatler, F., and Edmond, J. M.: On the marine geochemistry of cadmium, Nature, 263, 42-44, 1976.

Bruland, K.: Trace elements in seawater, in: Chemical Oceanography, 2nd Edition, vol. 8, edited by: Riley, J. P. and Chester, R., pp. 147-220, Academic Press, London, 1983.

Carriquiry, J. D., Sanchez, A., and Camacho-Ibar, V. F.: Sedimentation in the northern Gulf of California after cessation of the Colorado River discharge, Sediment. Geol., 144, 37-62, 2001.

Castro, R., Mascarenhas, S., Durazo, R., and Collins, C. A.: Seasonal variation of the temperature and salinity at the entrance to the Gulf of California, Mexico. Ciencias Marinas, 26(4), 561583, 2000.

Castro, R., Durazo, R., Mascarhenas, A., Collins, C. A., and Transviña, A.: Thermohaline variability and geostrophic circulation in the southern portion of the Gulf of California, Deep-Sea Res., I 53, 188-200, 2006.

Delaney, M. L., Linn, L. J., and Druffel, E. R. M.: Seasonal cycles of manganese and cadmium in corals from the Galapagos Islands, Geochim. Cosmochim. Acta, 57, 347-354, 1993.

Delgadillo-Hinojosa, F., Macias-Zamora, J. V., Segovia-Zavala, J. A., Torres-Valdes, S.: Cadmium enrichment in the Gulf of California, Mar. Chem., 75, 109-122, 1993.

Delgadillo-Hinojosa, F., Segovia-Zavala, J. A., Huerta-Díaz, M. A., and Atilano-Silva, H.: Influence of geochemical and physical processes on the vertical distribution of manganese in the Gulf of California, Deep-Sea Res. I, 53, 1301-1319, 2001.

de Villiers, S., Shen, G. T., and Nelson, B. K.: The Sr/Catemperature relationship in coralline aragonite: influence of variability in $(\mathrm{Sr} / \mathrm{Ca})$ seawater and skeletal growth parameters, Geochim. Cosmochim. Acta, 58, 197-208, 1994.

de Villiers, S., Nelson, B. K., and Chivas, A. R.: Biological controls on coral $\mathrm{Sr} / \mathrm{Ca}$ and $\delta^{18} \mathrm{O}$ reconstructions of sea surface temperature, Science, 269, 1247-1249, 1995.

Diaz-Rodriguez, G.: Estudio de la distribución vertical de manganeso y cobalto en la región de las grandes islas del Golfo de California, MSc Thesis in Coastal Oceanography, FCM-IIO, UABC. 91 pp., 2008.

Dominguez-Rosas, A.: Distribución vertical y temporal de níquel y cadmio en el Golfo de California, Tesis de Maestría en Oceanografía Costera, FCM-IIO, UABC. 97 pp., 2008.

Fallon, S. J., White, J. C., and McCulloch, M. T.: Porites corals as a recorder of mining and environment impacts: Misima Island, Papua New Guinea, Geochim. Cosmochim. Acta, 66, 4562, 2002.

Gagan, M. K., Ayliffe, L. K., Beck, J. W., Cole, J. E., Druffel, E. R. M., Dunbar, R. B., and Schrag, D. P.: New view of tropical paleoclimate from corals, Quat. Sci. Rev., 19, 45-64, 2000.

Goodkin, N. F., Hughen, K. A., Cohen, A. L., and Smith, S. R.: Record of Little Ice Age sea surface temperatures at Bermuda using a growth-dependence calibration of coral $\mathrm{Sr} / \mathrm{Ca}$, Paleoceanography, 20, PA4016, doi:10.1029/2005PA001140, 2005.

Grottoli, A. G. and Wellington, G. M.: Effect of light and zooplankton on skeletal $\delta^{13} \mathrm{C}$ values in the eastern Pacific corals Pavona clavus and Pavona gigantea, Coral Reefs, 18, 29-41, 1999.

Johnson, K. S., Coale, K. H., Berelson, W. M., and Gordon, R. M.: On the formation of the manganese maximum in the oxygen minimum, Geochim. Cosmochim. Acta, 60, 1291-1299, 1996.

Kahru, M., Marinone, S. G., Lluch-Cota, S. E., Parés-Sierra, A., and Mitchell, B. G.: Ocean-color variability in the Gulf of California: scales from days to ENSO, Deep-Sea Res. II, 51, 139-146, 2004.

Landing, W. M. and Bruland, K. W.: Manganese in the North Pacific, Earth Planet, Sci. Lett., 49, 45-56, 1980.

Lavin, M. F. and Marinone, S. G.: An overview of the physical oceanography of the Gulf of California, in: Nonlinear Processes in Geophysical Fluid Dynamics, edited by: Velasco-Fuentes, O. U., Kluwer Academic, the Netherlands, pp. 173-204, 2003.

Linn, L. J., Delaney, M. L., and Druffel, E. R. M.: Trace metals in contemporary and seventeenth-century Galápagos coral: records of seasonal and annual variability, Geochim. Cosmochim. Acta, 54, 387-394, 1990.

Lluch-Cota, S. E.: Coastal upwelling in the eastern Gulf of California, Oceanol. Acta, 23, 731-740, 2000.

Lluch-Cota, D., Lluch-Belda, D., Lluch-Cota, S., López-Martinez, J., Névares-Martínez, M., Ponce-Díaz, G., Salinas-Zavala, G., Vega-Velázquez, A., Lara-Lara, J.R., Hammann, G., and Morales, J.: Las pesquerías y El Niño, in: Los Impactos del Niño en México, edited by: Magaña, V. O., SG-SEP, México, pp. 137-178, 1999.

Matthews, K. A., Grottoli, A. G., McDonough, W. F., Palardy, J. E.: Upwelling, species, and depth effects on coral skeletal cadmium-to-calcium ratios $(\mathrm{Cd} / \mathrm{Ca})$, Geochim. Cosmochim. Acta, 72, 4537-4550, 2008.

Nameroff, T. J., Balistrieri, L. S., and Murray, J. W.: Suboxic trace metal geochemistry in the eastern tropical North Pacific, Geochim. Cosmochim. Acta, 66, 1139-1158, 2002.

Reuer, M. K., Boyle, E. A., and Cole, J. E.: A mid-twentieth century reduction inter-tropical upwelling inferred from coralline trace element proxies, Earth Planet. Sci. Lett., 210, 437-452, 2003.

Reyes-Bonilla, H.: Biogeografía y ecología de los corales hermatípicos (Anthozoa: Scleractinia) del Pacífico de México, in: Biodiversidad marina y costera de México, edited by: SalazarVallejo, S. I. and González, N. E., CONABIO-CIQRO, México D.F., pp. 207-222, 1993a.

Reyes-Bonilla, H.: Coral reef bleaching at Cabo Pulmo Reef, Gulf 
of California, México, Bull. Mar. Sci. 52, 832-837, 1993b.

Shen, G. T., Boyle, E. A., and Lea, D. W.: Cadmium in corals as trace of historical upwelling and industrial fallout, Nature, 328, 794-795, 1987.

Shen, G. T. and Boyle, E. A.: Determination of lead, cadmium and other trace metals in annually banded corals, Chem. Geol., 67, 47-62, 1988.

Shen, G. T. and Sanford, C. L.: Trace element indicator of climate variability in reef-building corals, in: Global Ecological Consecuences of the 1982-83 El Niño-Southern Oscillation, edited by: Glynn, P. W., Elsevier, New York, pp. 255-283, 1990.

Shen, G. T., Campbell, T. M., Dunbar, R. B., Wellington, G. M., Colgan, M. W., and Glynn, P. W.: Paleochemistry of manganese in corals from Galápagos Islands, Coral Reefs, 10, 91-100, 1991.

Shen, G. T., Cole, J. E., Lea, D. W., Linn, L. J., McConnaughey, T. A., and Fairbanks, R. G.: Surface ocean variability at Galápagos from 1936-1982: calibration of geochemical tracers in corals, Paleoceanography, 7, 563-588, 1992a.
Shen, G. T., Linn, L. J., Campbell, T. M., Cole, J. E., and Fairbanks, R. G.: A chemical indicator of trade wind reversal in corals from the western tropical Pacific, J. Geophys. Res., 97, 12689-12697, 1992b.

Shen, G. T.: Reconstruction of El Niño history from reef corals, Bull. Inst. Fr. Études Andines, 22(1), 125-158, 1993.

Slutz, R. J., Lubker, S. J., Hiscox, J. D., Woodruff, S. D., Jenne, R. L., Joseph, D. H., Steurer, P. M., and Elms, J. D.: Comprehensive ocean-atmosphere data set: release 1, Boulder, Colo. [NOAA and NCDC] 45 p., available online: http://www.cdc.noaa.gov/coads/ Release_1/coads.html, April 1985.

Trenberth, K. E.: The definition of El Niño, B. Am. Meteorol. Soc., 78, 2771-2777, 1997.

Wellington, G. M.: Calibration of stable oxygen isotope signature in Galápagos corals, Paleoceanography, 11(4), 467-480, 1996. 